\title{
Re-aligning the Triple Helix in post-Soviet Armenia
}

\author{
Annamária Inzelt ${ }^{1,2}$
}

\author{
Correspondence: \\ annamaria.inzelt@uni-corvinus.hu \\ ${ }^{1}$ IKU at Financial Research Co., \\ Felhévizi 24, 1023 Budapest, \\ Hungary \\ University of Szeged, Kálvária sugár \\ út 1, 6722 Szeged, Hungary
}

\begin{abstract}
In the age of Open Innovation, it is vital for a country in the lower middle-income bracket to free itself from those constraints which seriously weaken the links between science and industry. A descriptive analysis of these linkages in a post-Soviet economy_Armenia_-sheds some light on developments in policy-making which reinforce the interests of the private sector in the academic research and development (R\&D) sphere. However, the way of thinking is still predominantly the 'science-push' model—which is far removed from the (horizontal) Triple Helix concept. According to empirical analysis, the scarcity of innovative companies is a serious handicap for industry-science collaboration and if the private sector has little demand for knowledge or science, then the innovation system cannot be effective. Very few higher education institutions (HEls) or research institutes have devoted attention to the management of technology transfer, including necessary human resources. Human capacity problems, outdated infrastructure and an ageing workforce are significant barriers in scientific organisations. The autonomy of scientific organisations is an important asset which only half-exists in Armenia. On the escape route from a command economy, there are two potential traps on the way of autonomy: one occurs when the state overarches legal autonomy and creates a semi-autonomous situation; the other arises when the state is reluctant to regulate the framework for autonomous scientific organisations. Both exist in Armenia.
\end{abstract}

Keywords: Triple Helix; Post-Soviet economies; Armenia; Small economies

JEL Classification: 03; 05

\section{包 Springer}

(c) 2015 Inzelt. Open Access This article is distributed under the terms of the Creative Commons Attribution 4.0 International License (http://creativecommons.org/licenses/by/4.0/) which permits unrestricted use distribution, and reproduction in any medium, provided you give appropriate credit to the original author(s) and the source, provide a link to the Creative Commons license, and indicate if changes were made. 
French: Réajuster la Triple Hélice à l'Arménie post-soviétique

Résumé: A l'âge de l'innovation ouverte, il est vital pour un pays se situant dans la fourchette des bas-moyens revenus de se libérer des contraintes qui affaiblissent sérieusement les liens entre science et industrie. Une analyse descriptive de ces liens dans une économie post-soviétique, - l'Arménie -, donne un éclairage sur l'élaboration des politiques qui renforcent les intérêts du secteur privé dans la sphère académique de R\&D. Cependant, le mode de pensée prédominant reste le modèle d'innovation induit par la science, - qui est très éloigné du concept (horizontal) de Triple Hélice. Selon les analyses empiriques, la rareté de compagnies innovantes est un handicap sérieux pour la collaboration entre science et industrie, et, si le secteur privé a peu de demandes en termes de connaissance ou de science, alors le système d'innovation ne peut pas être efficace. Très peu d'institutions d'enseignement supérieur (IES) ou d'institutions de recherche ont prêté attention à la question de la gestion du transfert de technologie, y compris aux ressources humaines nécessaires. Les problèmes liés aux moyens humains, à l'infrastructure obsolète ou à une force de travail vieillissante sont des obstacles de taille pour les organisations scientifiques. L'autonomie des organisations scientifiques est un atout important pourtant quasiinexistant en Arménie. Pour sortir d'une économie planifiée, il faut éviter deux pièges éventuels sur le chemin de l'autonomie; l'un d'eux est que l'état chapeaute l'autonomie légale créant ainsi une situation de semi autonomie, l'autre consiste en ce que l'état est réticent à réguler les organisations scientifiques autonomes. Les deux cas de figure existent en Arménie.

Spanish: Activando la Triple Hélice en Armenia Pos-soviética

Resumen: En la era de la Innovación Abierta es vital para un país en el grupo de ingresos medianos-bajos liberarse de limitaciones que debilitan seriamente los vínculos entre la ciencia y la industria. El análisis descriptivo de estos vínculos en una economía post-soviética_Armenia-iluminará la evolución de la formulación de políticas que refuerzan el interés del sector privado en el ámbito de la investigación y desarrollo académicos. Sin embargo, la forma de pensar sigue siendo predominantemente el modelo de "ciencia-primero" que está muy lejos del concepto de Triple Hélice. De acuerdo a estudios empíricos, la escasez de empresas innovadoras es un serio obstáculo para la colaboración industria-ciencia y si el sector privado tiene poca demanda de conocimiento científico, el sistema de innovación no puede ser eficaz. Muy pocos institutos de investigación (incluidas las universidades) han prestado atención a la gestión de la transferencia de tecnología y los recursos humanos necesarios para esta tarea. Y la tarea se hace más ardua gracias al insuficiente capital humano, infraestructura obsoleta, y una fuerza laboral envejecida (desactualizada). En adición, la autonomía de las organizaciones científicas es un activo importante que sólo existe a medias en Armenia. A medida que Armenia sale de un modelo de economía planificada, debe confrontar dos trampas potenciales estableciendo autonomía académica: si el estado regula con una mano muy dura, estas organizaciones no alcanzarán nada más que a una semi-autonomía; mientras que si el estado es reacio a regular, la autonomía de estas organizaciones carecerá de protecciones básicas. Sorprendentemente, ambas situaciones se presentan a la vez en Armenia. 
Chinese: 重新定向后苏联时代亚美尼亚的三螺旋

摘 要: 在开放创新时代,就中低等收入国家而言，至关重要的是从严重削弱科学-产 业联系的那些束缚中解脱出来。对于在苏联解体后亚美尼亚经济中的这些联系 的描述性分析,揭示了在政策制定方面的发展——在学术研发领域增强私营部门 的利益。然而,其思维方式仍然主要是远离(横向)三螺旋概念的“科学推动”模

式。根据实证分析,创新型企业的缺少是科学-产业合作的重大障碍,如果私营部门 对知识或科学的需求甚少,那么创新体系便无法有效。很少有高校或科研院所对 技术转移管理予以重视,包括必要的人力资源。人的能力问题、陈旧的基础设施和 劳动力老龄化是科学组织发展的重大障碍。自主性对于科学组织非常重要,但在亚 美尼亚只存在一半。在逃离计划经济的道路上,在自主的方式上有两个可能的陷 阱:一个发生在国家凌驾于司法独立性之上并形成半自主的情况时; 另一个则出现 在国家不愿意为自主的科学组织调整框架的时候。在亚美尼亚两者同时存在。

Russian: Построение Тройной спирали в пост-советской Армении

Аннотация: В век открытых инноваций жизненно-необходимым для страны, относящейся к группе стран с доходами ниже среднего, является освобождение от подобных ограничений, т.к. они значительно ослабляют связи между наукой и промышленностью. Сравнительный анализ таких связей в условиях постсоветской экономики в Армении выявил ряд успешных наработок в политической сфере, направленных на укрепление интересов частного сектора в академическом секторе исследований и разработок. Однако, в основе типа мышления продолжает преобладать модель, в которой доминирующая роль отведена науке, что очень отличается от трехспиральной модели инноваций. В соответствии с результатами эмпирического анализа, нехватка инновационных компаний является серьезным ограничением на пути развития сотрудничества между промышленностью и наукой, и в условиях, когда частный сектор проявляет малый интерес к научным результатам, такая инновационная система не может быть эффективной. Лишь небольшое число образовательных или научных институтов уделяют внимание на трансфер технологий, а также необходимость качественных кадровых ресурсов. Проблемы человеческого потенциала, устаревшая инфраструктура и стареющие рабочие кадры формируют существенные барьеры в научных организациях. Независимость научных организаций является их важным свойством, что лишь частично наблюдается в Армении. На пути перехода от командной экономики существует две потенциальных ловушки, сопряженные с автономией: первая встречается, когда государство излишне контролирует юридическую независимость института, что приводит к его полуавтономному существованию; второй вариант наблюдается в тех случаях, когда государство с неохотой управляет работой автономных научных организаций. Оба варианта встречаются в Армении. 
Portuguese: $O$ Realinhamento da Hélice Tríplice na Armênia pós-soviética.

Resumo: Na era da Inovação Aberta, é vital para um país de renda média a inferior o empenho para se libertar das limitações que enfraquecem seriamente as ligações entre a ciência e as empresas. A análise descritiva dessas ligações em uma economia pós-soviética - Armênia - lança uma luz sobre o desenvolvimento de políticas públicas que reforçam os interesses do setor privado na esfera acadêmica de pesquisa e desenvolvimento. Entretanto, a maneira de pensar predominante ainda é o modelo do "science-push" que ainda está muito longe do conceito (horizontal) da Hélice Tríplice. De acordo com análises empíricas, a escassez de empresas inovadoras prejudica seriamente a colaboração entre as empresas e a ciência, e se o setor privado tem pouca demanda por conhecimento ou ciência, logo o sistema de inovação não tem como ser efetivo. Muito poucas Instituições de ensino superior e institutos de pesquisa têm dedicado atenção à gestão da transferência tecnológica, incluindo os recursos humanos necessários. Problemas na capacitação humana, de infraestrutura obsoleta e de envelhecimento da força de trabalho são barreiras significativas para as organizações científicas. A autonomia das organizações científicas é um ativo importante, mas que só existe parcialmente na Armênia. Com relação a rota de fuga de uma economia controlada, existem duas potenciais armadilhas no caminho para a autonomia: uma ocorre quando o Estado se sobrepõe à autonomia legal e gera uma situação de semi autonomia; a outra ocorre quando o Estado está relutante em regulamentar o quadro para as organizações autônomas cientificas. Ambas são verificadas na Armênia.

\section{Multilingual abstract}

Please see Additional file 1 for translation of the abstract into Arabic.

\section{Introduction}

Armenian research and development (R\&D) expenditure on GDP approaches $0.25 \%$; specifically, the limited public funding available for R\&D is mainly allocated to the National Academy of Sciences, ${ }^{1}$ whilst universities typically receive less public support for research. The Internationally Open Innovation model has generated considerable interest in the competition for highly skilled partners on a world-wide basis, and responding to these enormous challenges is much more difficult for less internationalised, developing countries operating with what we might term the bare skeleton of government-industryscience collaboration than for the more advanced countries. All post-Soviet economies, both in Europe and in Asia, are marked with the footprints of the Soviet model and the break-up of the Soviet Union (USSR) itself. These independent post-Soviet economies have faced many challenges in this new age of Open Innovation, and they must also develop their own national innovation model to be able to approach any form of Triple Helix (TH) model in which government, industry and science can cooperate effectively.

Without going into detail concerning the features of the Soviet era, it is worth whilst to take into account four 'footprints' of the old model:

(1) The command economies operated on the so-called science-push linear model of innovation, which meant a one-way relationship involving academic science, applied industrial research and the introduction of new products or technology within socialist enterprises. That model was very well suited to a centralised planning system (Hanson and Pavitt 1987). 
(2) The Soviet republics were integrated somehow into a 'confederation' where many governmental functions were missing at individual state level. As was acknowledged by the last President of the Soviet Union, Mikhail Gorbachev, in an interview, 'Although the word 'Union' was a part of the Soviet Union's name, it wasn't really a union. The republics had only very limited sovereignty and competencies.' (Der Spiegel On-line, International, January 16, 2015).

(3) In that innovation system, horizontal collaboration among the triple helix actors hardly existed. Vertical collaboration involving government industry and science was geographically dispersed, and regions (republics) also cooperated vertically. Mismatches between the different components of innovation systems were interwoven with a peculiar division of labour among the Soviet republics.

(4) Advances in the military sector were remarkable, but these successes were not repeated in other sectors; in fact, the progress of high technology in the military sector had very limited impact on the development of the civilian sector.

The failings of the system were coded into the institutional structure, the economic environment and the 'command-integration' of the Soviet republics. To counter the inherited systemic failure, newly independent states (post-Soviet economies) are re-coding their existing institutions, establishing institutions which they previously lacked, such as patent offices, and searching for opportunities for industry-science links both domestic and cross-border.

From the group of post-Soviet economies, this paper examines Armenia, largely since this republic was an important scientific location for the whole of the Soviet Union-and was often labelled as a 'scientific hub' during the Soviet era. During the same period, knowledge-based companies operated in other Soviet republics (mainly in Russia) and these implemented Armenian inventions. The break-up of the USSR and national independence led to an interruption in the existing (command-led) industry-science linkages (ISLs), and industry was able to employ R\&D-based new products obtained outside the national borders. $R \& D$ was downsized radically for a variety of reasons:

a. One part of the R\&D capacity became obsolete and was restricted to domestic needs.

b. The mass emigration of highly educated human capital diminished the still relatively high ratio of human capacity in the R\&D sphere.

Armenia was selected from the post-Soviet republics as a good example to use to investigate how the unbalanced level in the development of science and industry and weak international relationships influence the viability of the Triple Helix model. As in many post-socialist countries, scientific actors are present and perform well in several fields, but innovative industrial actors are few and far between. These characteristics differ from those of non-post-socialist countries (such as Latin-American or Southeast Asian) at similar development levels-where, however, industry is more businessoriented and more entrepreneurial but where scientific potential is weaker.

A further problem for post-Soviet republics was the collapse of command-led crossrepublic (Union-level) linkages. Following the disintegration of the Union, cross-republic 
cooperation within the Union did not develop into international collaboration-so causing many similar problems in post-Soviet economies. The Armenian case may highlight the search for ways out of these double traps towards a well-functioning TH model, in which ISLs are both efficient and effective and can work across borders. Hence, our study may offer some guidance to Armenian TH actors as well as to countries with similar problems. ${ }^{2}$

Before we examine actual TH actors, a short section provides some information on Armenia to help to give readers some context of the country. The following sections focus on how the country can develop its own innovation system, how it can create an appropriate economic environment for the commercialisation of scientific results and the innovativeness of business organisations. Firstly, the study assesses the role of government as the facilitator of ISLs, with particular emphasis on the legal framework, including intellectual property rights. It then examines a number of initiatives to promote ISLs, describes key actors and provides an assessment of the current situation. The final part draws some conclusions.

The methodology applied comprises the following: (1) a systemic screening exercise of current legislation and of practice regarding ISLs in Armenia, (2) interviews and roundtable consultations with key $\mathrm{TH}$ figures in Armenia and (3) an analysis of a variety of statistical information.

\section{Armenia-a country both ancient and new}

Armenia is one of the smaller post-Soviet Asian economies $\left(29,743 \mathrm{~km}^{2}\right)$ situated along the route of the Great Silk Road and landlocked in the South Caucasus. GDP per capita is US\$3208 (IMF: World Economic Outlook Database, April 2014). The population is $3.3 \mathrm{~m}$, almost two thirds of which is urban, and the adult literacy rate is $99.6 \%$ (UNESCO 2013).

Even if each of the Caucasian and Central Asian post-Soviet states show some similarities during and after the Soviet period, each has some peculiarities rooted in its history-for example, the level of economic development, the population's literacy rate, the predominant faith and its scientific capabilities.

'At the dawn of history, Armenia was one of the cradles of civilization. Millennia before the Christian era, the economy, arts, and popular traditions of Armenia had developed to such an extent that her culture stimulated Egypt, Greece, and Rome, both materially and spiritually.' (Bauer, cited by Eduard Abrahamyan (2013)) One of the earliest Christian civilisations, its first churches were founded in the fourth century. Armenia boasts a history longer than most other European countries. ${ }^{3}$ The orbit of Armenia was affected by a number of cultural influences and empires. In medieval ages, it frequently oscillated between Byzantine, Persian, Mongol or Turkish control, as well as enjoying periods of independence. The country was divided between the Persians and Ottomans in the sixteenth century; eastern Armenian territories became part of the Russian Empire in the early nineteenth century, whilst the remainder stayed within the Ottoman Empire. Its rich cultural and architectural heritage combines elements from different traditions.

At the end of World War 1, the independent Republic of Armenia was proclaimed, but in the early 1920s, the country was incorporated into Bolshevist Russia along with Georgia and Azerbaijan. In 1988, a devastating earthquake killed some 25,000 people. ${ }^{4}$ 
In 1991, when the Soviet Union was dissolved, Armenia's independence (declared in 1990) was officially recognised. After independence, the country was quickly drawn into a bloody conflict with Azerbaijan over the mainly Armenian-speaking region of Nagorno-Karabakh (in late Soviet days, there were anti-Armenians pogroms in Azerbaijan). There has been a fragile cease-fire with Azerbaijan over the disputed Nagorno-Karabakh region since 1994. Following the cease-fire in 1994, Armenia's borders with Turkey and Azerbaijan remain closed-which has produced economic isolation.

Poor political relationships with her neighbours have either created weak or have destroyed cross-border collaboration in many fields from rail transport to ISLs with neighbouring countries. ${ }^{5}$ Some changes may occur as Armenia joins the Eurasian Economic Union (EEU) from $2015 .^{6}$

Due to the war, Armenia's transition from a centralised command to a market economy was more dramatic than for some other countries. ${ }^{7}$ The 1994 cease-fire provided good opportunities to move towards a market economy, and the Armenian government embarked on an economic reform programme which brought some stability and growth and a total change to a market economy. The economy had started to recover in the early 2000s, and by the mid-2000s, the legislation and policy focus had shifted towards science and innovation. In this period, a number of Acts were adopted and a range of high-level policy decisions were taken (see the list in UNECE (2014), p. 11).

Armenia is a country with a 1600-year history of literacy, as education has been traditionally highly rated (UNESCO 2013). The country has always prided itself on its highly educated human capital and R\&D capacities and achievements during the Soviet era. The education and scientific systems were affected equally in a negative way as all other sectors during the 1990s (see more in Arzumanjan (2006)).

Whilst the Government realised the strategic importance of education and science for the development of Armenia, it did very little after the break-up of the Soviet Union to preserve its human capital and prevent the scientific and technological capabilities from deterioration. Armenia has always experienced waves of emigration, but the exodus of recent years has caused real alarm. It is estimated that Armenia has lost up to a quarter of its population since independence.

This historic pattern of emigration has produced a huge, affluent diaspora-generally regarded as one of Armenia's most important competitive advantages, and it is widely predicted that this can be used effectively to generate a significant, positive impact on the economic development of the country. The diaspora could well be of great assistance by means of FDI, joint ventures, boosting exports and technology transfer.

In 2006, the World Bank report (p. 102) found that Armenia has 'an extremely weak and fragmented system: lack of linkages among the productive sector, the universities and the research institutes.' The situation has not yet changed: the country was ranked 125th in terms of university-industry collaboration in global rankings, the position having deteriorated by 39 places since 2005 (The National Competitiveness Report of 2011/2012, cited by Makaryan (2013)). The position is no better in respect of the World Economic Forum's Global Competitiveness Report 2014. Out of 144 economies, Armenia ranks relatively high in terms of the availability of scientists and engineers (75) and by PCT (Patent Cooperation Treaty) patent applications per head of population (53). In terms of company spending on $R \& D$, however, it ranks only 
102nd, although this is an improvement over 2013 (109). Its ranking seems stable in terms of the quality of scientific research institutions 105 (in 2013 106). Nevertheless, in relation to university-industry collaboration in $R \& D$, the country slipped back from 107 (2013) to 112. Universities with research activities are strong candidates for ISLs, whilst R\&D carried out in Higher Education Institutions (HEIs) has several advantages, including a close connection to teaching-which, of course, aids wider knowledge diffusion. However, as a legacy of the Soviet system (HEIs were responsible for teaching), Armenia has a relatively weak HE research system.

\section{Literature context}

Analysing industry-science linkages draws together a wide variety of strands of literature relating to systems of innovation. One of these is the national innovation system (NIS) as first described by Freeman (1987), Lundvall (1992) and Nelson (1993). Later concepts followed and were developed further by many authors by means of both theoretical and empirical studies.

Another strand of literature focuses on only three key actors of NIS and their relationships-namely the triadic relationships linking university, industry and government and known as the TH model. The founding fathers of this model are Etzkowitz and Leydesdorff (1995), (1998), (2000); Etzkowitz (2008), (2011) who recognised the growing importance of these actors and their interactions. ${ }^{8}$ According to the TH model, universities have to play a more active and prominent role in supporting innovativeness in knowledge societies. As scientific knowledge becomes increasingly important for innovation and new business development, universities are playing an enhanced role in contemporary economic growth. These developments have changed the traditional function and behaviour of both universities and companies, so leading to the emerging redeployment of universities in implementing the third mission and to changing the innovation model of companies in what we now term 'Open Innovation'.

The central idea behind open innovation (Chesborough 2003; 2006; Chesbrough et al. 2006) is that in a world of widely disseminated knowledge, companies cannot afford to rely entirely on their own research but should instead buy or license processes or inventions from other actors, either from other firms or from universities and research organisations. Literature on the third mission of universities focuses on the emergence and dimensions of the third mission which extends the traditional missions of teaching (first) and research (second), having a vice-versa impact on their first and second missions. This concept presents university-industry collaboration from the university perspective (Laredo 2007; Mollas-Gallart et al. 2002; Nedeva 2008).

The TH model emphasises that, whilst fulfilling their traditional functions, each of the three major institutional spheres (government, university and industry) also takes on the role of the others in performing new roles too. Institutions taking nontraditional roles are viewed as a major potential source of innovation. (Etzkowitz 2008)

During recent decades, an enormous number of authors have contributed to deepen our knowledge of both the TH model and the Third Mission of universities. A few should be mentioned in terms of their main concerns. There have been many case studies at national or regional level investigating collaboration involving these three spheres (e.g. Boardman 2009; Inzelt 2004, 2010; Geuna and Rossi 2011; Arza and 
Vazquez 2010; Chataway and Hewitt 1999; Dutrenit and Arza 2010; Liang et al. 2012; Sutz 2000) which identified many characteristics and institutional settings in which these relationships are evident. Perkmann et al. (2013) provides a review of the literature on university-industry relations. There are also efforts to measure the interactions between the Triple Helix actors in order to reveal trends and patterns (summarised by Meyer (2012)).

It is only recently that, based on the insights gained through these various studies, a Triple Helix system concept is being elaborated focusing on the components, relationships and functions in the interactions (Ranga and Etzkowitz 2013).

Although most of these concepts were initially built up in developed countries, they are also currently applied in developing countries (just mention few of them that are focusing on CEECs: Ranga and Etzkowitz 2010; Inzelt 2004; Radosevic 1999, 2003). By tradition, the literature usually speaks of university-industry collaboration rather than of industry-science collaboration. In the countries originally studied, the universities are the main producers of scientific knowledge, whilst in most others, such as all of the post-Socialist and post-Soviet economies, the institutes of Academies of Science are more important generators of knowledge. Hence, in analysing Armenia, this paper always refers to ISLs to cover all important science producing actors.

Before going into any detail in the investigation of Armenian ISLs, it worth recalling a Latin-American author Jorge Sabato (1975, summarised by Carvalho de Mello (2011)) whose 'Triangle model' with a 'Privileged State' was one of the predecessors of what we now call the Triple Helix model. In his model, Sabato identified several features of government-industry-science relationships which show many similarities in developing countries without a democratic system. Even if Latin-American countries which were under military rule with authoritarian and nationalist regimes were not the same as the Soviet model, if they had a science and technology policy, they were mission-oriented (Ergas 1986). The transformation processes in Latin America as well as in post-Soviet countries reveal common factors. In the Latin-American countries, a major challenge-as Sabato proposed-was the gradual shift from the 'Dominant State' model to a new, more market-oriented system which encourages 'trilateral initiatives for knowledge based economic development' and strategic alliances among Government institutions, universities and private business. This is also an important task for formerly command-led post-socialist countries. The trials and errors on the road to transition characterise this process in Armenia (Arzumanjan 2006; Khnokoyan 2009, 2012; Makaryan 2013, and Yerznkyan 2011).

Scientific organisations, companies and the government are equally important actors in ISLs, although each of these three pillars plays a different role. In the current stage of development and transition to a market economy, the government is the key actor in creating a suitable environment, defining the framework and promoting initiatives for ISLs. In the next section, we summarise governmental efforts to facilitate the redeployment of scientific organisations and to provide a better framework for ISLs.

\section{The government as facilitator of industry-science collaboration in Armenia}

The transition from the linear innovation model of the command economy towards the richer and more sophisticated concepts of industry-science relationships which are evident in market economies produces more tasks for post-Soviet states than for 
post-Socialist countries (in other words, the Soviet Union's previous satellites). One of these extra tasks for post-Soviet states originates from the disintegration of the somehow integrated command economies.

A few legislation and government functions existed only at Union level, and newly independent states had to learn to create them. Within the Union, the ISLs were interwoven among the 'integrated' republics 'by command' and rarely existed at republic level. The collapse of the Soviet Union (the dominant state) and the disintegration of its republics interrupted command-led science-industry linkages between republics, and there was a serious lack of confidence in rebuilding such partnerships and linkages. The first challenge for governments in the post-Soviet republics was to enact new legal regulations and then to define policy and introduce measures to assist in achieving the targets.

It has to be kept in mind the government is still not a full-fledged facilitator. In Armenia-similar to other post-Soviet states-the government still has an interventionist function in business matters. The division of the roles between governmental agencies and business sector has not been well defined yet. More incentives and further changes in legislation need to broaden the horizontal (direct) ISLs and to diminish indirect (vertical) ISLs. Such kind of changes can make collaborations less complicated and more efficient.

In the following section, we ask how the Armenian government can facilitate a move towards a TH model.

\section{Legal regulations relating to interaction}

Following the cease-fire in the mid-1990s, Armenia made tremendous efforts to build a modern legal system promoting a knowledge-based, innovation-friendly economy. In the legislation procedure, more significant progress has been evident since 2006, although further refinement is necessary. Two government resolutions should be mentioned at this point: in 2006, the Ministry of Economy was designated the government body responsible for developing and implementing innovation policy; in 2007, the State Committee of Science was set up as a new committee within the Ministry of Education and Science and became the lead player in the government control of science.

At this point, we think it appropriate to examine five laws which are important from an ISL perspective.

\section{Laws redefining the intellectual environment}

Three laws are important here: the Law on Scientific and Technological Activity, the Law on State Support for Innovation Activity and the Law on Intellectual Property Rights (see the details in UNECE (2014)). This section focuses only the Intellectual Property Right (IPRs)-related issues that are good examples to illustrate the extra tasks for post-Soviet states in transforming the system.

Laws on Intellectual Property Rights were enacted between 1998 and 2010. The laws on IPRs follow international norms and produce a sound legal environment for IPR protection. However, practical problems arise in relation to Patent Cooperation Treaty (PCT) patents and patenting abroad. ${ }^{9}$ As in many less advanced, small and medium size countries, the Patent Office does not have the authority to issue PCT patents, acting only as a receiving office for Armenian PCT applications and advising on 
possible next steps. Where applicants wish to file a patent application abroad, the role of the Patent Office is generally limited to providing basic information-for example, data on patent fees and patent attorneys.

The relatively young Armenian Patent Office has a limited capacity to evaluate the novelty of inventions on a world scale. Patent registration abroad is costly and uncertain, and the owners of Armenian-registered patents are unsure whether they will obtain patent rights from strong patent offices (USPTO, EPO and JAPTO). This also makes licence agreements somewhat risky. Patent protection is, therefore, often limited to Armenia, with patentees facing the risk that their codified knowledge may be imitated abroad.

\section{Transforming scientific organisations}

New legislation on the National Academy of Sciences of Armenia (NAS) and on Higher Education (HE) is a prerequisite for reformulating scientific knowledge producers and developing their capability to play a part in successful ISLs. The introduction of legislation is clearly a gradual procedure.

The Law on the National Academy of Sciences of Armenia (enacted 2011) declares that the Academy is a self-governing, scientific non-profit organisation with a special status, operating within a governance system determined by the government (see the details in UNECE 2014). This law opens up the door of Academy to spin-off activities to a potential financing role for the business sector including foreign actors. However, the law leaves open the question of whether the Academy Institutes can be involved in launching spin-off, or raising early-stage finance, as well as regulations regarding IPR-related issues and technology transfer offices (TTOs). Some freedom in the detailed regulation of these issues would be useful, although more concrete regulatory provisions in certain areas could provide greater clarity to develop initiatives.

The Academy is the official advisor to the Government on scientific matters, whilst there is a consultative role on innovation for state administrative bodies in the Academy Presidium. However, there is no equivalent advisor on innovation matters, and the Academy naturally represents the linear 'science-push' model. ${ }^{10}$

The Law on Higher Education (LHE) of 2004 and the Law on Education of 1999 are working well, and there have been significant reforms in higher education-e.g. joining the Bologna Process in 2005; granting semi-autonomy to state universities, allowing the establishment of private universities and introducing a quality assurance system. However, current legislation does not regulate on the issue of IPRs in employment contracts in HEIs, the treatment of inventions and the establishment of technology transfer functions to support the creation of spin-off companies.

These deficiencies are no surprise given that HEIs are regulated not only by the Law on HE but also by the Law on State Non-Commercial Organisations (SNCO) (2001). The latter has an important impact on HEIs, which strongly affects their commercial opportunities and ISLs. The World Bank report (2013) has highlighted certain contradictions between these laws which limit the autonomy of organisations, including opportunities for commercialisation and ISLs. According to existing legislation, HEIs are separate legal entities and neither the Ministry of Education and Science (MOES) nor the founder (the government) can restrict their autonomy, whilst, according to the Law on SNCOs, the founder should make any final decision related to the activities of HEIs. Given this conflict, it is inevitable that HEIs do not really exercise their full autonomy. 
State HEIs are not legally required to follow a model Charter developed by the MOES, which limits autonomy and academic freedom. However, most state HEIs adopted the Charter without modification, as revisions require Government approval (World Bank 2013, para 38). Exceptions exist: the Yerevan State University and the Armenia State Engineering University have deleted the norms limiting their autonomy from their charters. Others may follow in the future.

The Law on SNCOs restricts engagement in entrepreneurial activities to those with Government approval, and so limiting potential HEI revenue. There are, again, a few exceptions, e.g. the Charter of the Yerevan State Medical University (adopted by the Government on September 15, 2005) allows university involvement in a wide range of business areas (which earns $19 \%$ of its revenue from sources other than state funding and tuition fees) and the Architecture and Construction University (28\%); even the Yerevan State University earns only $9 \%$ from other sources (World Bank 2013). The recent change in the legal status of the Agrarian University from an SNCO to a foundation has given the university an opportunity to diversify funding sources-namely, to broaden their private sector linkages.

Overall legislative changes have created the basic conditions for ISLs but have not tackled a number of constraining factors. The new institutional settings offer better opportunities for collaboration, although the Law on NAS and the Law on HEIs still leave the doors for linkages with industry only half-open. As The World Bank report stated, the Law on HE 'neither allows nor motivates HEIs to be actively engaged in research and development' (2013). The engagement of HEIs in commercial activities is restricted to those which are specified in their charters, and the Law on Scientific and ScientificTechnical Activities does not clearly specify the ownership of research outcomes (Para 54).

\section{Policies for the knowledge-based innovative economy}

Armenian policy retains the science-push perspective dating from the Soviet era. For Armenian innovation policy, it is important to move from a dominantly supply-side innovation policy towards a policy including demand-driven innovation, even if the loss of a large share of former innovation-related demand (such as the Soviet militaryindustrial complex and the space industry) has been a significant challenge (Arzumanjan 2006). Since the first decade of this century, the Republic of Armenia (RA) is gradually building up her innovation policy as we may see in the most recent policy documents-which may be summarised as follows:

A key element of industrial policy is the Strategy of export-led industrial policy (2011), which focuses on key export sectors, including the production of brandy, pharmaceuticals and biotechnology precision engineering. These industries are good candidates for ISLs, since they are exposed to international competition, and the policy emphasises the expansion of competitive production and new start-ups.

The Concept Paper on innovation policy (2011) defines the mission of innovation economy formation and comprehensive strategy for the design and implementation of national goals. Within this policy, the 'Cooperation project' aims to support innovative, scientific and technical, industrial programmes and projects, and address information gaps in various industrial spheres. It also includes the development of a database of national information resources (Khnokoyan 2012). 
The Strategy of Science Development (2010) targets a science-based economy by 2020, competitive at the European level in terms of basic and applied R\&D. Implementation of this strategy is through the Action-Plan (2011). Policy documents emphasise the importance of commercialisation and industry-science collaboration. However, budget allocation does not fully support this important goal. For example, the share of natural sciences and technology sciences in the state budget decreased by $9 \%$ points from 2003 to 2011. Agricultural sciences have a small share and have also been losers in the structural shift (see the detailed figures in Table 1).

This shift in the research budget structure is hardly promising for upgrading industry-science collaborations.

Several steps are important in strategy formation. Firstly, the Science and Technology Strategy covered the period 2003-2010 and were followed by another for the period 2011-2020. The Strategy was completed by the National Technology Innovation Programme to 2020 and National Programme on High Technology Development to 2020.

\section{Mechanisms for interaction between public research institutions and enterprises}

Policy is implemented through action plans, annual programmes and other initiatives contained in the state budget. In the mid-2000s, it was hard to identify any ISL-related measures and incentives for business innovation. The World Bank report noted 'In Armenia... there seems to be a dearth of measures that seek to stimulate firms to undertake their own technology development. Policy is focused much more on measures which support institutions in undertaking S\&T activities on behalf of industrial firms. There are no policy measures that support and facilitate actions by firms themselves... grant-based mechanisms are notably absent' (2006 pp. 105-106). However, recent efforts to promote new financial models, technology parks, and special training that may all support future collaborations and the ICT sector's development have also received considerable attention.

One of the missions of the Strategic Plan for the Development of Science (20112015) relates to ISLs: 'fundamental scientific organisations are to promote both economic output and the applied nature of research.' However, responsibility for policy implementation in relation to ISLs is divided among three governmental organisations: the State Committee of Science, the Ministry of Education and Science, and the Ministry of Economy. There is little emphasis on ISL existing

Table 1 Proportion of gross expenses on research by fields of science (\%)

\begin{tabular}{lllll}
\hline Fields of sciences & 2003 & 2006 & 2008 & 2011 \\
\hline Total & 100.0 & 100.0 & 100.0 & 100.0 \\
- Natural & 51.3 & 43.6 & 42.9 & 42.7 \\
- Technology & 37.9 & 40.7 & 35.7 & 28.8 \\
- Medical & 2.5 & 3.1 & 3.2 & 2.2 \\
- Agricultural & 2.6 & 2.7 & 2.7 & 1.7 \\
- Social & 1.8 & 3.4 & 6.4 & 3.7 \\
- Humanities & 3.9 & 6.5 & 9.1 & 21.0 \\
\hline
\end{tabular}

Source: author's calculation from Statistics on Science 2003-2011, Scientific and technological works section, table on gross expenses, on research works in million Drams 
programmes, with the exception of recent initiatives of the State Committee on Science (with a limited budget) including the following: ${ }^{11}$

- Implementation of specific programmes, including the principle of co-financing with the private sector

- Business incubators, technology parks

- Software development, conferences and exhibitions for commercialization of research results

\section{Main tools}

Public resources for innovations policy are very limited, and many programmes are supported by foreign or international organisations. The main incentives for ISLs are budget support through programmes and managed by direct allocations or calls for tender. The government has sought to improve the transparency of selection processes by publishing selection criteria and scoring systems for allocating state support, but there is scope for further improvement. The inclusion of business representatives in programme development may help, although the risk of state capture is significant in a small country with a limited number of competitors and independent evaluators.

The State Committee for Science (SCS), established in 2007, is a key actor and has $3 \%$ of the total science budget at its disposal. Activities of relevance to ISLs include support for the following:

○ Research projects with innovative potential;

- Commercialization of research outcomes; and

○ Infrastructure modernization projects.

Within the framework of these supporting programmes of the SCS, innovation projects are co-financed with the private sector.

The innovation fund mainly supports SMEs, although the SCS wishes-together with the private sector-to extend support to include medium and large firms. A support programme for patenting activity abroad is also under consideration. Overall, very limited non-budgetary sources are devoted to promoting ISLs, and these mainly originate from international grants and donations. Whilst developing public-private partnerships (PPPs) and cost-share projects are stated goals, there is limited information on the regulation of PPPs, incentives for cost-sharing and the modalities for the joint exploitation of research findings.

\section{Other tools for supporting SILs}

Other tools such as tax incentives can be important in promoting ISLs. On the demand side, innovative public procurement can be used to encourage collaboration. The Ministry of Finance establishes the criteria for public procurement, although innovation issues are not explicitly taken into account. The Ministry of Economy opened an office in Silicon Valley to promote Armenian products, signing contracts with Armenian firms. Free economic zones, intended primarily to attract foreign investment in the country, may also have the desirable side effect of 
creating demand for new knowledge and supporting ISLs, with the first zone focusing on the IT sector.

Overall, Government programmes for ISLs remain limited, with linking or joint programming activities between different government actors lacking. This makes reaching critical mass for financing through co-programming and co-budgeting more difficult. It is still unclear whether the firms in the free economic zones will use the accumulated knowledge and skilled workforce for routine tasks or for research collaboration.

Armenian Science, Technology and Innovation (STI) budget is limited and devotes its significant share to grand projects. Very limited budgetary reosurces are devoted to ISLs.

\section{ISLs implementation}

In most technologically advanced economies, companies are the main implementers of innovation activities, including their collaboration with research organisations. This contributes significantly to both knowledge supply and innovation demand.

Business R\&D activity is important not only because of knowledge generation but also for assimilating and using new knowledge. An important indicator is the ratio of Business Expenditure on R\&D (BERD) to Gross Expenditure on R\&D (GERD). So far, BERD data has not been available for Armenia. Naturally, the disaggregation of business R\&D activities by intramural and extramural work is also unknown.

Data on patenting by domestic firms may be indicative of both invention capabilities and absorption capacity. Those firms that devote some attention to R\&D can better monitor new knowledge and have more opportunities for technology innovation. Table 2 shows the annual number of patent applications and of patents granted by type of patentee.

Most patent applications were received from HEIs with a much smaller share from domestic firms and branch research institutes not linked to the NAS. There has been a decline in the number of patent applications from NAS institutes, possibly due to IPR management issues.

\section{Industry}

The Armenian innovation system, as in many post-Soviet economies and post-socialist countries, is not yet business-centred. Generally speaking, there are three different types of industrial R\&D: exploratory, exploitative, and imitative. Each type has the potential to create or drive competitive advantage, albeit with varying degrees of

Table 2 Yearly patent data by type of patentee

\begin{tabular}{|c|c|c|c|c|c|c|c|c|}
\hline \multirow[t]{2}{*}{ Type of organisations } & \multicolumn{4}{|c|}{ Patent applications } & \multicolumn{4}{|c|}{ Granted patents } \\
\hline & 2009 & 2010 & 2011 & 2012 & 2009 & 2010 & 2011 & 2012 \\
\hline HE organisations & 23 & 31 & 29 & 34 & 36 & 15 & 40 & 26 \\
\hline Institutes of NAS & 9 & 5 & 4 & 4 & 11 & 4 & 6 & 3 \\
\hline Other kinds of institutes and domestic firms & 12 & 10 & 15 & 9 & 15 & 19 & 12 & 17 \\
\hline Total & 44 & 46 & 48 & 47 & 62 & 38 & 58 & 46 \\
\hline
\end{tabular}

Source: Intellectual Property Agency of RA 
novelty, depending on the company's capabilities and business strategy. The characteristics of collaboration according to the type of industrial $R \& D$ have a strong impact on possible ISLs.

The Armenian business sector is not well developed. Armenian domestic companies tend to be small and are often family-owned and family-managed. Limited managerial skills and a domestic environment with low levels of competition are factors reducing a company's incentive to innovate, and hence their demand for knowledge. Skilled expatriates in the Armenian diaspora, in addition to philanthropic donations and investment in key sectors (e.g. the IT sector and tourism), have a leading role to building international linkages by supporting exhibitions, road shows and conferences-crucial, given a limited domestic market. These events are also help to put Armenian science and skilled people on the map. However, to date, there has been a reliance on one-off contracts to help domestic companies in difficult economic conditions, with limited lasting commercial partnerships (although they help to survive a difficult economic situation and to start on the development path).

The main issue for the science sector is the modernization of industry. The sectoral structure of Armenian industry, as export data show, is largely traditional, with a high proportion of so-called low tech sectors (raw materials, food and beverages and light industry). It is true that traditional industries have some economic advantages which it is important to exploit. However, this sectoral structure and limited innovation in the business sector is often focused on imitative $R \& D$ and innovation activities, resulting in few $R \& D$ linkages with universities or research institutes.

The presence of MNCs has increased in the past few years, but only a handful act as a driving force for innovation-a precondition for industry-science collaboration. Around $60 \%$ of companies are in Armenian ownership, with foreign ownership largely accounted for by North America (20 \%) followed by Europe (10 \%) and Russia (8 \%). ${ }^{12}$ Foreign affiliates operate in certain high-technology and scientific fields (such as aerospace and ICT) where Armenia has inherited strength and still maintains the capacity to supply new knowledge to industry. In a few, often export-oriented, better performing sectors, foreign companies have linkages with Armenian science organisations. Some examples are shown in Table 3.

These companies are more often involved in collaborative training programmes with universities and the associated staff recruitment, than R\&D linkages. However, given the small domestic market, an internationally open innovation model may hold promise-one under which firms based abroad partner domestic scientific organisations in international business-science networks. Cross-border ISLs have a certain tradition in Armenian, although the meaning of open innovation system is significantly different from the Soviet-type ISLs' labour division, when Armenia was home to several leading R\&D centres with firms in other Soviet republics as customers (such as the space and computer industries). The collapse of the Soviet Union brought disintegration, and these command-led, mission-oriented science-push linkages were interrupted. Nonetheless, the international open innovation model can only be appropriate for certain sectors. It is also crucial for the fairness of cross-border collaboration.

In the high-technology sector, outsourcing has been a clear trend. Armenian advantage includes good engineers with lower salaries, and, according to several managers, around $70 \%$ of outsourced tasks are routine jobs and only $30 \%$ involve development, 
Table 3 Foreign companies collaborating with a university or a NAS institute

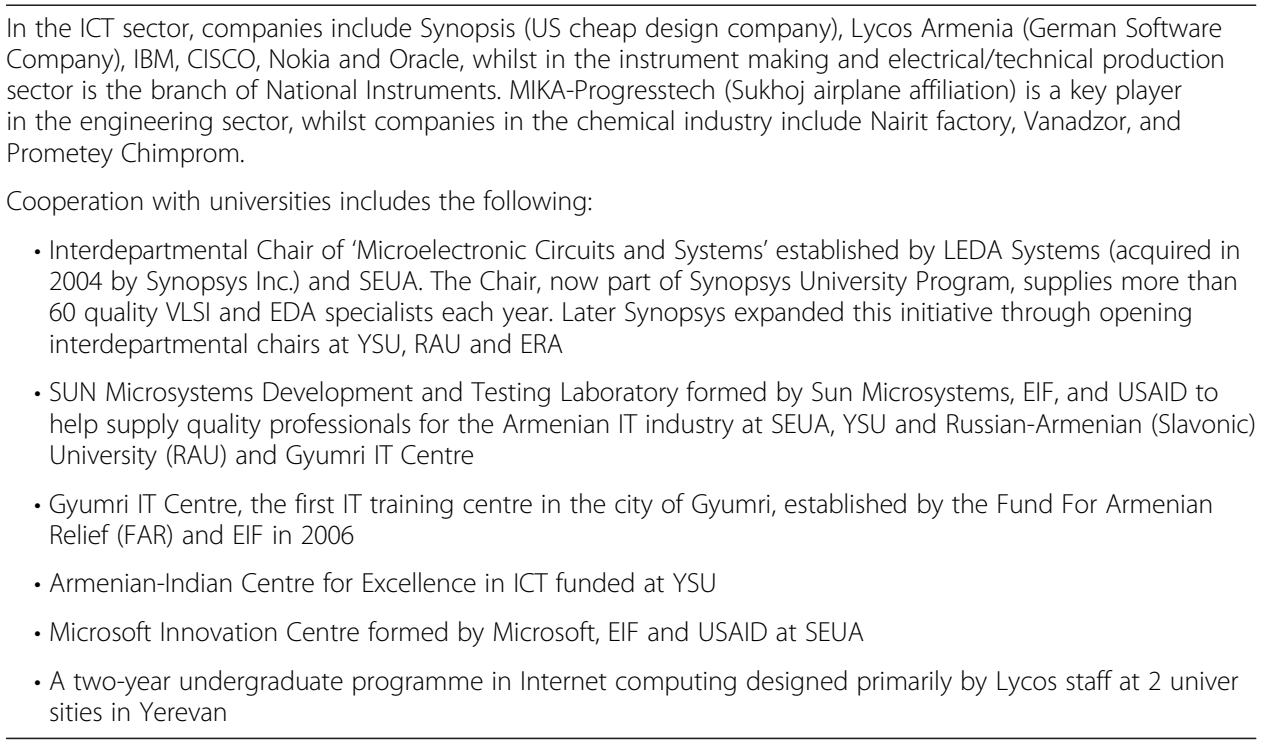

Extracted from various reports and interviews

with industry generating a limited demand for innovation (Ogma, Margasoft). There is scope for the Government to introduce incentives for industry to innovate, boosting demand for ISLs, and also putting innovation on the agenda for FDI policy. Broader international collaboration can facilitate the participation of Armenian scientific organisations in innovation networks. Upgrading norms and standards can also create demand for innovation-e.g., energy efficiency standards can produce an increased demand for more advanced building insulation technologies.

\section{Scientific institutions as potential collaborators}

In Armenia public research is carried out in three different types of organisation. Some of the specificities of these organisations are the legacy of the Soviet system and they have been transformed during last two decades, as in other post-Soviet countries (Inzelt 1999; Radosevic 1996, 2003; Arzumanjan 2006; Khnokoyan 2009, 2012; Ranga and Etzkowitz 2010; UNECE 2014).

Generally, HEIs' may be partners for exploratory and exploitative research-based innovation. Among universities with research activities, a distinction may be made between so-called think-tank universities and do-tank universities (Cooper 2009).

For think-tank universities, their criterion is academic excellence. They serve the advancement of science and, in doing so; they focus on basic research and in several fields (such as biotechnology) to applied research also. Public funding is crucial to this type of university. In only a few fields of science do business collaborations (using private resources) occur.

The role of do-tank universities is different. The main research target of this type of universities is to serve appropriately the emerging need of industry. Their research activities are applied and/or practice-based. According to Cooper (2009) do-tank universities are not leaders but followers of industrial development. This statement is true in advanced countries, where domestic industry has a key role in creating demand 
and providing private funding for do-tank universities, which tend to follow industrial development.

Although it is a continuous spectrum, some research universities lean more towards the think-tank model (e.g. Yerevan State University) and are mix of the think-tank and the do-tank model (e.g. the State Engineering University of Armenia) and others towards the pure do-tank model (e.g. the Armenian National Agrarian University). Armenia lacks research-intense universities in the international sense, and there are few research-oriented universities. Most HEIs can be partners for industry in teaching, training and retraining, but a more select group are candidates for ISLs, including Yerevan State University, the Medical University, the State Engineering University, the Architectural University, the American University and the Agrarian University. There are no apparent differences in government initiatives or resource allocation between the different types of university, although thematic funding tends to favour researchoriented (think-tank type) universities.

NAS institutes are largely dedicated to fundamental research, remaining the main $R \& D$ performers in Armenia, but also contribute to training young researchers and industrial innovations. They are traditional sites for conducting the sorts of fundamental research typically carried out in HEIs in many advanced economies. The institutes of the Academy can be partners for exploratory think-tank and exploitative do-tank researchbased innovations.

In many countries, other research institutes are the key technology supporting organisations (TSIs) with strong business linkages. In several countries (e.g. Japan, South Korea) TSIs are important supporters of innovative small businesses. They are potential partners for exploitative research- and imitation-based innovation. In Armenia, research institutes independent of NAS are typically the successors of Soviet-era sectoral research organisations significantly reformed and presenting a diverse picture. Some have very limited prospects if they do not have information regarding possible competitors. The level of scientific performance can vary greatly within and among institutes. A number of laboratories have strong international reputations and partnerships, with support from sources such as the NATO Science for Peace and Security Programme or the EU Enterprise Network. Such collaborations provide access to up-to-date scientific literature and knowledge, but almost all laboratories require modernization of their equipment and scientific instruments. The cutting-edge research laboratories frequently use home-made equipment to study their fields. Poor conditions may lead to alternative world-class inventions, but there is no guarantee of good scientific results. Research under poor conditions is much more time-consuming and well performing labs are better candidates for ISLs.

\section{IPR management in scientific organisations}

Currently, a wide variety of arrangements are in place regarding IPR management, with no legal obligation for research organisation to specify internal rules or terms in employment contracts regarding IPR governance. A requirement to specify IPR issues, without detailed prescriptions, would not conflict with institutional autonomy. At the Armenian State Engineering University, the university is the owner of inventions, but is obliged to mention the name(s) of the inventor(s). Where a company has contracted 
the research, the applicant (and the owner) of the patent is the firm but in the application must mention the name of the inventor, who retains the right to scientific publication. Where inventions result from a collaborative research project, the ownership issue has not been regulated yet. The Medical University makes a distinction between inventions originated from university research (in which case the university is the owner) or from other activity. The NAS Institute for Physical Research (an SNCO) has incorporated IPR-related issues in its standard contract of employment.

\section{Technology transfer and other match-making organisations}

Technology Transfer is part of the process of commercialising scientific research results. The main aim of technology transfer is to turn scientific discoveries into marketable products so that the economy and society can benefit from the research as quickly and efficiently as possible. Commercialization can take various forms-e.g., licensing agreements or spin-off firms, joint ventures and partnerships to share the risks and rewards of bringing new technologies to market.

\section{The technology transfer office}

It will be a process of trial-and-error to find the relevant type(s) of technology transfer office (TTO) to fit the Armenian NIS. A distinction can be made between two types of office: TTOs in science performing organisations and independent (or stand-alone) for-profit or not for-profit entities.

At the research institute or university, the TTO is a service dedicated to the management and licensing of the intellectual property created, combining knowledge of research assets and forthcoming inventions with intellectual property, licensing, business development, marketing, and other technology transfer-related legal expertise. The Institute for Physical Research (Ashtarak) has created a TTO in 2013 as a forerunner among the institutes of NAS.)

Very few HEIs or research institutes have devoted attention to the management of technology transfer, including necessary human resources, with the establishment of invention-based spin-offs viewed as a separate matter for science and technology parks.

\section{Stand-alone technology transfer organisations}

Self-standing technology transfer infrastructure, often with state support, can also help serve ISLs, typically closer to commercialization. Examples include Viasphere, Gyumri, and Andron techno parks, and the Innovation Centre in Vanazori. Support for commercialization always requires a physical infrastructure, e.g., an Enterprise Incubator Foundation and the Technology Transfer Association (TTA), although their bridging function is important for ISLs. The TTA-operating since 2001-connects Armenian science with business organisations using the regular tools of the "science-push" innovation model, establishing links between technology owners and organisations looking for innovative solutions. TTA members are knowledge producers with advanced technologies, mainly from the natural sciences and engineering-related fields (Organic and Inorganic Chemistry, Instrumentation, Materials' Science, Molecular Biology, Biotechnology, Machinery, Electronics). TTA collaborates with a range of other domestic and foreign organisations, including business consultants and technology designers. 
The TTA maps all Armenian research groups, excluding the military-related, to form a complete list of existing technologies and new technologies in the pipeline. The TTA employs experts from Armenia and from CIS countries, the latter proving less expensive than Western expertise but with a weaker knowledge of marketing and other implementation issues. According to the assessment of the TTA, technologies which are the best candidates for commercialization can be found at the Institute of Physical Chemistry, the Institute of Molecular Biology and the Institute of Materials Science. TTA has limited staff and is funded from success fees. A new concept is to launch the Distributed Science Technological Park (D-STEP), conceived as a techno park "without walls".

\section{Industry-science linkage}

The key to the whole innovation process is interactive partnership among companies and between companies and other actors such as universities and R\&D institutes. The scale of linkages ranges from ad hoc consultation to joint research activity (Inzelt 2004).

In countries where ISLs are weak, the main challenge for universities is typically to establish the preconditions for ISLs: advancing research methods, and organisational structure, research governance and education. It is crucial to provide a well-educated labour force with the knowledge and skills required by industry. Armenian HEIs have made major efforts to achieve this and they have upgraded their teaching curricula, often in collaboration with employers. Many universities training technical specialists also offer various business courses, although some, such as innovation management skills (intended to nurture an entrepreneurial spirit among graduates) require more attention. A small number of universities also provide courses in management, entrepreneurship, marketing and the treatment of IPRs, which could be adopted by more HEIs. The teaching of foreign languages such as Russian and English are also considered extremely important for the development of a quality technical and managerial cadre (Armenian ICT Sector 2012, State of Industry Report). ICT training has significantly improved in recent years.

According to the science-push innovation model - which is still strong in Armenia, research institutes and universities seek companies for commercialization, with information gathering and knowledge dissemination as important functions at research-oriented institutions. For financial reasons, many academic employees have one or more additional jobs in industry, with positive side-effects for ISLs and knowledge dissemination.

Table 4 summarises the types of ISLs, with Armenian examples. The type and function of ISLs characterise the depth of collaboration. Deeper collaborations (e.g. $R \& D$ collaborations) are typically the most durable. "Archipelago" and "Arm's length" collaboration are also evident in developed countries. However, early signs of the TH collaboration (the research outsourcing form of R\&D collaboration) may be found, particularly in the few research-intensive universities and institutes of NAS.

Even basic or shallow forms of ISLs can lead to progressively deeper collaboration. Whilst firms are quite reluctant to participate in ISLs, development aid plays an important role in mobilising foreign MNCs in a few areas to invest in universities' facilities. Examples include the following: research laboratories at the Yerevan State Engineering University; Internet and web technology laboratories established by Lycos 
Table 4 Type, function and deepness of collaborations

\begin{tabular}{|c|c|c|c|}
\hline Depth & Type & Function & Armenian examples \\
\hline \multirow[t]{5}{*}{$\begin{array}{l}\text { Isolated } \\
\text { (Archipelagos) }\end{array}$} & $\begin{array}{l}\text { Ad hoc consultation of firm } \\
\text { at universities }\end{array}$ & \multirow[t]{3}{*}{$\begin{array}{l}\text { Information } \\
\text { gathering }\end{array}$} & \multirow{3}{*}{$\begin{array}{l}\text { Conferences have been organised } \\
\text { for building linkages typically in } \\
\text { specific sectors (e.g. ICT, medical) }\end{array}$} \\
\hline & $\begin{array}{l}\text { Regular discussions between } \mathrm{U} / \mathrm{I} \\
\text { on various issues }\end{array}$ & & \\
\hline & $\begin{array}{l}\text { Purchase of university research results } \\
\text { on ad hoc basis }\end{array}$ & & \\
\hline & $\begin{array}{l}\text { Lectures of firm employees held } \\
\text { at universities }\end{array}$ & \multirow[t]{2}{*}{$\begin{array}{l}\text { Knowledge } \\
\text { dissemination }\end{array}$} & \multirow{2}{*}{$\begin{array}{l}\text { YSU/Faculty of Radio physics/ } \\
\text { Synopsis lecturers trained the staff } \\
\text { to disseminate best practice }\end{array}$} \\
\hline & $\begin{array}{l}\text { Lectures of faculty members } \\
\text { held at firms }\end{array}$ & & \\
\hline \multirow[t]{6}{*}{$\begin{array}{l}\text { Far distance and } \\
\text { Arm's Length } \\
\text { Cooperation }\end{array}$} & $\begin{array}{l}\text { Employing faculty members as } \\
\text { regular consultants }\end{array}$ & $\begin{array}{l}\text { Information } \\
\text { gathering }\end{array}$ & $\begin{array}{l}\text { Joint working as professors at } \\
\text { university and engineers at firms } \\
\text { (YSMU, YSEU and YSU) }\end{array}$ \\
\hline & $\begin{array}{l}\text { Coaching of firm employees by } \\
U \text { researchers }\end{array}$ & \multirow[t]{3}{*}{$\begin{array}{l}\text { Knowledge } \\
\text { dissemination }\end{array}$} & \multirow{5}{*}{$\begin{array}{l}\text { YSU/Faculty of Radio physics/ } \\
\text { Synopsis PhD students conducting } \\
\text { research }\end{array}$} \\
\hline & $\begin{array}{l}\text { Training of firm employees by } \\
\text { professors }\end{array}$ & & \\
\hline & $\begin{array}{l}\text { Joint supervision of theses by } \\
\text { U/I members }\end{array}$ & & \\
\hline & $\begin{array}{l}\text { Joint publications by professors } \\
\text { and firm employees }\end{array}$ & \multirow[t]{2}{*}{$R \& D$} & \\
\hline & $\begin{array}{l}\text { Joint IPRs by professors and firm } \\
\text { employees }\end{array}$ & & \\
\hline \multirow[t]{7}{*}{ TH (horizontal) } & Formal R\&D cooperations—joint R\&D & \multirow[t]{4}{*}{$R \& D$} & \multirow[t]{2}{*}{ YSMU/Pharmaceutical Faculty) } \\
\hline & $\begin{array}{l}\text { Regular acquisition of university } \\
\text { research }\end{array}$ & & \\
\hline & \multirow[t]{2}{*}{ Formal R\&D cooperation—outsourcing } & & - Dental research firm in Garni \\
\hline & & & - Arpimed pharmaceuticals \\
\hline & Access to special equipment of $I / U$ & \multirow{2}{*}{$\begin{array}{l}\text { R\&D } \\
\text { infrastructure }\end{array}$} & \multirow[t]{3}{*}{ YSEU—NIs, IBM, Nokia softwares } \\
\hline & Investment in university's facilities & & \\
\hline & $\begin{array}{l}\text { The types that are included into TH } \\
\text { (horizontally deep) group may contain } \\
\text { R\&D collaboration }\end{array}$ & $\begin{array}{l}\text { Knowledge } \\
\text { dissemination } \\
\text { and information } \\
\text { gathering }\end{array}$ & \\
\hline
\end{tabular}

Source: modified version of Inzelt (2004)

Europe, EIF, and Sourcio CJSC at SEUA and YSU in 2005; Regional Mobile Application Laboratory founded in 2011 for Eastern Europe, South Caucasus and Central Asia under the joint project of InfoDev, Government of Finland and Nokia. A previously ministry-controlled sectoral institute, the Yerevan Computer Research and Development Institute became a joint stock company. Its majority shareholding was purchased by a Russian company, which itself was a successor to a former Soviet research institute (the Armenian branch is larger than the Russian mother company). Although not eligible for basic funding from Government sources, the institute can be a contractor for state-funded projects. Table 5 provides some examples of ISLs at leading Armenian universities.

In advanced market economies, a very common model for commercialization is launching science-based spin-off companies. Their main aims are to commercialise new knowledge created within a scientific organisation. In Armenia, there are no government programmes for spin-offs. As was discussed in the section on legal issues, 
Table 5 Examples on ISLs for commercialization

Some of the Armenian universities maintain close cooperation with private businesses.

Yerevan State University has notable collaborations with Synopsis, which has a branch in the Faculty of Radio physics, providing education programmes at all levels, including for doctoral students, and professors are coming from Synopsis too. Mikaprogresstech, a branch of the Russian Sukhoi airplane company, also works directly with students of the university, whilst the Central Bank works with staff and students of the Faculty of Commerce.

Yerevan State Medical University works closely with the Ministry of Defence in relation to military medicine, although commercialization potential from this remains unclear. Other ISLs include a Garni located dental research small firm, and contracts with clinics such as military hospitals and universities. The university has its own pharmaceutical company, with which faculties collaborate. The Department of Pharmacy management has conducted a 'Study of pharmaceutical markets' with the International Society for Pharmaco-economics and Outcomes Research (USA), whilst Department of Pharmacy and Arpimed pharmaceutical company are collaborating in identifying compounds occurring naturally in Armenian plants and herbs (e.g. oregano, lavender, smoked tree, Arabia gum).

The State Engineering University of Armenia hosts research centres for IBM, Nokia and Oracle. National Instruments collaborates in research supervision and providing supporting software. The company's Armenian office has a mission to support linkages between National Instruments and Armenian scientific organisations and small firms.

Source: author's interviews at the universities

spin-off creation is constrained both by law and charters at HEIs. The Law on the Academy, however, neither supports nor hinders their establishment, but the limited opportunities result in organisations being trapped in a less-than-stable form within scientific organisations-and in lost benefits for both semi-entrepreneurs and scientific organisations. ${ }^{13}$ This phenomenon is not unique in the world; it was also the situation in Hungary until the mid-2000s-before, that is the enactment of the relevant law on HEIs and Academy (Inzelt 2008).

\section{Barriers to industry-science linkages}

Framework conditions for ISLs have improved in recent years, thanks to various Government initiatives. However, measures are not always coordinated, and budget allocations for promoting linkages, collaboration, and networking are very limited. Management of scientific work, collaborations and commercialization at research organisations remains weak. In Armenia, the current legal regime is not fully supportive of spin-off creation for commercialization by research organisations. The recent Law on the National Academy of Science gave greater freedom to institutes relating to ISLs than HEIs have. The Ministry of Education is able to grant special charters to universities on an individual basis. Existing regulation concerning patenting or licensing is well designed in several organisations but unclear in others. Without more general clarification regarding the ownership of inventions or patents, potential business partners are reluctant to participate in this type of ISL.

Scientific institutes and governmental organisations still often think in terms of the science-push model, whilst research capabilities have limited commercial visibility. Human capacity problems, outdated infrastructure and an ageing workforce are significant barriers in scientific organisations.

Barriers on the industry-side are the lack of interest and capability for innovation. Industry lacks intramural and extramural $R \& D$ activities, and there is little inventionbased entrepreneurship. Cross-border ISLs offer potential rewards, but, despite some grass-root initiatives, it is not easy to scale up to participate in internationally open innovation networks. 


\section{Conclusions}

The Armenian Triple Helix model still bears the footprints of the former Soviet model-which is why the model has required a redefinition of government role from a prescriptive 'dominant state' towards a facilitator of innovation, industry-science collaborative relationships. Armenia needs to improve still further its legal conditions for industry-science collaboration, to create incentives for changing the attitude of researchers and to build an entrepreneurial spirit.

Armenia has made tremendous efforts to redeploy its legal system and to formulate science and innovation policies which are more relevant for the country. In the legislation procedure, the country made an excellent start with its new IPR legislation which provides good opportunities to organise the commercialization of research results. The IPR laws and the office itself play a crucial role in upgrading the country's patenting culture, highlighting the value of invention. There are good examples of the positive handling of IPR in scientific organisations, but many have not paid enough attention to the matter. The reason might be a lack of expertise or of basic awareness. Further development of the law on HE and NAS has paved the road for ISLs and public-private partnerships, but the current legislative environment offers only limited opportunities for ISLs.

In respect of science and innovation, a combination of supply- and demand-driven approaches of relevant policies can support ISLs and collaboration in open innovation networks. The supply-side needs to strengthen science and technology development capabilities; at the same time, on the demand side, more relevant measures are urgently needed for business organisations to encourage innovative activities of companies. The greatest problem for the government is to whet the corporate appetite for innovation. Different types of incentive may help to enhance the innovation activities of local SMEs, including both family-owned firms in traditional industries and MNCs-encouraging them to move beyond imitative innovation and to build linkages with Armenian science organisations in their innovation activities.

In Armenia, there is a scarcity of innovative industrial players looking for science partners for exploratory research. In respect of exploitative research, there are some companies (albeit still few) who need scientific partners, whilst a slightly larger (but still limited) number of companies approach universities for assistance with imitative research. Clearly, the scarcity of innovative companies is a serious handicap for industry-science collaboration and if the private sector has little demand for knowledge or science (or is outmoded, lacking relevant human and physical capabilities), then the innovation system cannot be effective.

Beyond the strengthening of scientific capabilities, academics have to understand the language of business in order to promote durable, large-scale collaborations or set up knowledge-based spin-off companies. The autonomy of scientific organisations is an important asset which only half-exists in Armenia. On the escape route from a command economy, there are two potential traps on the way of autonomy: one occurs when the state overarches legal autonomy and creates a semi-autonomous situation; the other arises when the state is reluctant to regulate the framework for autonomous scientific organisations. Both exist in Armenia.

ISLs have significant offspring: the most frequent aim of collaboration is to improve the quality of human resources through up-dated knowledge and enhanced skills. Few 
opportunities exist for upgrading science-business collaboration, although effective linkages are vital to transform knowledge into wealth. An examination of Armenian ISLs is justified, since, apart from some visible progress, the science and innovation management capabilities are still weak in every relevant organisation (business, science institutes, and STI state administration), and the technology transfer function is widely scattered in scientific organisations.

Given the small domestic market, an internationally open innovation model may hold out some hope-on the basis that foreign companies partner with domestic scientific organisations in international business-science networks. It is extremely important that the TH model can cross national borders and offer much more effective working conditions for small developing economies. The mode of collaboration is strongly influencing the success or failures of the innovation model, and good cross-border collaboration can generate science-based income for Armenia, help to retain human resources in the country and upgrade the nation's scientific capacities.

Armenia is some half-way between the 'far distance' and 'arm's length' Triple Helix models. To reach the arm's length TH model and continue towards the horizontal (interaction) TH model is time-consuming, and the adjustment of each player to an open innovation system is an important precondition to upgrading linkages among them.

Lessons from the TH model in advanced countries are highly important, but there is no single model which fits all. Science-industry-government relationships are influenced by the level of development, the historical and institutional traditions of individual countries. Armenia can learn from both groups of countries: advanced countries and in some way successful developing economies devoting special attention to the transformation practices of post-socialist economies.

A vision of the catching-up, innovative economy in Armenia able to compete successfully internationally makes it absolutely necessary to encourage businesses to be innovation-oriented and universities to develop not only their research activities but also their collaboration with industry.

\section{Endnotes}

${ }^{1}$ The Academy in Armenia was founded in 1943 on the basis of the Armenian Branch of the Soviet Academy of Sciences, which was established almost 10 years earlier, in 1935.

${ }^{2}$ This paper is partially based on the fifth chapter of Industry-Science linkages and collaboration in the innovation process in Innovation Performance Review of Armenia, conducted and edited by UNECE (United Nations Economic Commission for Europe) Secretariat and published by the United Nations New York and Geneva, 2014. The other chapters of the Review provide lot of insights in transformation of Armenian Soviet-type NIS.

${ }^{3}$ The Armenian language is part of the Indo-European family, but its alphabet is unique.

${ }^{4}$ For the historical description, the following sources were used: www.sci.am; The Great Soviet Encyclopaedia (2010) Abrahamyan (2013) Ambartsumian (1960). Akademiia nauk Armiansko (1968); BBC profile on Armenia; Gasimov, Zaur: Kaukasus in European 
History Online, Institute of European History, Mainz 2011, last retrieved: 21 February 2013.

${ }^{5}$ Many experts emphasise the importance of cross-border collaborations, including the opportunities for reintegration of post-Soviet countries (so-called Eurasian integration) (Vinokurov 2013). A discussion on the advantages and disadvantages of reintegration goes beyond the scope of this paper.

${ }^{6}$ Founding members are: Belarus, Kazakhstan and Russia (see more details in EBRD (2014)).

${ }^{7}$ Despite high economic growth figures recorded before 2008, roughly $30 \%$ of the population were still living below the poverty line in early 2013. Unemployment and poverty remain widespread.

${ }^{8}$ Analysing the Armenian national innovation system Yerznkyan (2011) highlighted the definition of the NIS has to broaden further by adding an external institution, namely the Armenian Diaspora, to the internal elements of the NIS (which may fit the TH model also). The diaspora as an external institution does not mean the internationalisation (or globalisation) of NIS. Initially, the State should have the leading role in mobilising and directing the resources of universities and scientific institutions. The diaspora can participate in coordinating activities between different institutions.

${ }^{9}$ Under Soviet patent regulations, the right to an invention was regulated by a document entitled 'Author's certificate', which had the same legal meaning as today's patents. By this Law, the inventor, or author, lost his or her ownership of the invention. Inventions were declared state property, which could be used by anyone without the author's permission (the author was entitled to compensation for the exploitation of the invention, which amounted to $2 \%$ of annual economic output) (Bernie R. Burrus 1962, The Soviet Law of Inventions and Copyright, 30 Fordham L. Rev. 693 (1962). Available at http://ir.lawnet.fordham.edu/flr/vol30/iss4/3). The Union's patent office was located in Moscow, and there were no offices and human resources in the majority of republics.

${ }^{10}$ Neither technology upgrading nor innovation based on R\&D alone, but upgrading technology, requires increased absorption capacity and improved skills in the labour force. Non-technological innovations are also required non R\&D-based capabilities. These are the reasons why it is problematic if the Academy has too heavy an advisory role in innovation policy formulation.

${ }^{11}$ Extracted from the Strategic Plan Development of Science in 2011-2015, enacted 2010, translated version of strategy action-plan.doc, Appendix N 2, Table 4 The government's 2010 The $\mathrm{N}$ npnzưu氏).

${ }^{12}$ Source: industry_stat_2012, calculated from table on number of company ownership by geography.

${ }^{13} \mathrm{~A}$ few examples are State University of Engineering has created some start-up companies jointly with the American MNC, National Instruments. The employees are professors and employees. Yerevan State University can provide a good example of a very promising start-up company. The head of the High Power Laser Laboratory has established a private small company (the staffs comprise of ten professors and five $\mathrm{PhD}$ students who work only part-time there, as they have other jobs at the university. The present CEO of this company is an American Armenian; the MNC owns 83 \% (the 
value of shares is three times higher than in its first year of existence, 2007.) The university has no share in the company as the rules applying did not allow it to establish a company. However, the company is located inside the university where it rents a room adjoining the department and pays a monthly rent of $\$ 50$ to the university. The professors are working in their own room at the department and the company will voluntarily invest $\$ 2000$ in the YSU's commercialization programme. Under these circumstances, the department and company are interwoven. This start-up company has good potential to valorise accumulated research. They have some promising clients in the American military industry who are interested in certain technology from the department which may solve border control problem (this technology relate to detecting tunnels up to $200 \mathrm{~m}$ below ground, whilst others can detect only to a depth of $10 \mathrm{~m}$ ). There is also a contract in the pipeline with the Russian Federation-based 'Koroljov'-owned company, and the Kazakh government has approached the company with a view to establishing a joint venture.

\section{Additional file}

Additional file 1: Translation of the abstract into Arabic. (PDF $271 \mathrm{~kb}$ )

\section{Acknowledgements}

The author wishes to express her gratitude to Armenian colleagues who shared their knowledge and devoted time for interviews and roundtable discussions. Special thanks to colleagues who commented on the previous versions of this paper: Jose Molero, Mikayel Melkumyan, Igor Bortnik, Jose Palacin, Christopher Athey, Phan Thi Tuc Anh, Tran Thi Van Hoa, Chie Iguchi, Takabumi Hajashi, Henry Etzkovitz, Irina Dezhina and anonymous referees for their valuable critical notes.

Received: 24 February 2015 Accepted: 30 September 2015

Published online: 15 October 2015

\section{References}

Abrahamyan E (2013) In: Simonyan H (ed) Introduction in Archaeological Heritage of Armenia. Hushardzan Publishers, Yerevan, p 9

Akademiia nauk Armiansko SSR za 25 let. (1968) Yerevan, BBC profile on Armenia, 2012. http://news.bbc.co.uk/2/hi/ europe/country_profiles/1108052.stm.

Ambartsumian V (1960) Nauka v Armenia za 40 let. Yerevan

Arza V, Vazquez C (2010) Interactions between public research organisations and industry in Argentina: analysis of channels and benefits for researchers and firms. Sci Public Policy 37(7):499-511

Arzumanjan T (2006) Current issues of research, development and innovation in Armenia. Int J Foresight Innov Policy 2(2):133-145

Boardman PC (2009) Government centrality to university-industry interactions: university research centres and the industry involvement of academic researchers. Res Policy 38:1505-1516

Burrus, BR (1962) The Soviet Law of Inventions and Copyright, 30 Fordham L. Rev. 693 (1962). Available at: http:// ir.lawnet.fordham.edu/flr/vol30/iss4/3

Carvalho de Mello JM (2011) Presentation on TH9 conference

Chataway J, Hewitt T (1999) Managing institutional changes in the science and technology systems of Eastern Europe and East Africa. Dev Pract 9(1-2):88-102

Chesborough HW (2003) The era of open innovation. Sloan Manage Rev 44, 3(Spring):35-41

Chesbrough H (2006) Open business models: how to thrive in the new innovation landscape. Harvard Business School Press, Boston

Chesbrough H, Vanhaverbeke W, West J (eds) (2006) Open innovation: researching a new paradigm. Oxford University Press, Oxford

Cooper DM, (2009) A new university mission of social responsiveness? Critical perspectives on a 'second academic revolution. In: Paper presented at the American annual congress of ASHE (Association for the Study of Higher Education). Vancouver

Dutrenit G, Arza V (2010) Channels and benefits of interactions between public research organisations and industry: comparing four Latin American countries. Sci Public Policy 37:541-553

EBRD (2014) Transition report, innovation in transition. tr.ebrd.com

Ergas, H. (1986) Does Technology Policy Matter? Centre for European Policy Studies, pp. 59

Etzkowitz H (2008) The Triple Helix: university-industry-government innovation in action. Rutledge, New York and London, London, pp 1-164

Etzkowitz H (2011) The triple helix: science, technology and the entrepreneurial spirit. J Knowledge-based Innov China $3(2): 76-90$ 
Etzkowitz H, Leydesdorff L (1995) The Triple Helix - University-Industry-Government relations: a laboratory for knowledge based economic development. In: EASST review., pp 14-19

Etzkowitz H, Leydesdorff L (1998) A Triple Helix of university-industry-government relations: introduction. In: Industry \& higher education, vol $12 \mathrm{nr}$. 4)., pp 197-258

Etzkowitz H, Leydesdorff L (2000) The dynamics of innovation: from 'National Systems' and 'Mode-2' to a Triple Helix of university-industry-government relations. In: Research policy, vol 29., pp 109-123

Freeman C (1987) Technology policy and economic performance. Pinter, London

Geuna A, Rossi F (2011) Changes to university IPR regulations in Europe and the impact on academic patenting. Res Policy 40(8):1068-1076

Hanson P, Pavitt K (1987) The comparative economics of research, development and innovation in east and west: a survey. Harwood Academic Publishers, Chur

Inzelt A (1999) Science, technology and innovation: institutional and behavioural conditions for innovative industrial development. In: Brigitta W, Wolfgang P (eds) Frameworks for industrial policy in central and Eastern Europe. Ashgate International Publishing, Aldershot, UK, pp 163-192

Inzelt A (2004) The evolution of university-industry-government relationships during transition. Res Policy 33(6-7):975-995

Inzelt A (2008) Strengthen and upgrade regional capabilities (Regional University Knowledge Centre Program in Hungary). Romanian J Econ 26:133-154

Inzelt A (2010) Collaborations in the open innovation era. In: Ekekwe N (ed) Nanotechnology and microelectronics. IGl Global, USA, pp 61-86

Khnokoyan A (2009) "Financial mechanisms of scientific and innovation policy of the Republic of Armenia" "Инновационный путь развития экономики:Стратегии и перспективи" ("Innovation way of the developing the economy: strategies and prospective"), in Saratov-Yerevan., pp 81-86

Khnokoyan A (2012) National innovation system and the development of scientific and innovation policy in the Republic of Armenia. Sci Innov Ukrainian Rev J Future 75-83

Laredo P (2007) Revisiting the third mission of universities: toward a renewed categorisation of university activities? High Educ Policy 20:4

Liang L, Chen L, Wu Y, Yuan J (2012) The role of Chinese universities in enterprise-university research collaboration. Scientometrics 90(1):253-269

Lundvall B-A (1992) National systems of innovation. Pinter, London

Makaryan G (2013) The assessment concept of innovative level of Armenia's industry, RUEA, presentation

Meyer M (2012) Triple Helix indicators—a bibliometric perspective. Hélice (Triple Helix Assoc Newsl) 1(2):4-6

Mollas-Gallart J, Salter A, Patel P, Scott A, Duran X (2002) Measuring third stream activities, report to the Russel group universities. SPRU, Brighton

Nedeva M (2008) New tricks and old dogs? The 'third mission' and the re-production of the university. In: The world yearbook of education 2008: geographies of knowledge/geometries of power: framing the future of higher education. Routledge, New York, pp 85-105

Nelson R (1993) National innovation systems. Oxford University Press, New York

Perkmann M, Tartari V, McKelvey M, Autio E, Broström A, D'Este P, Fin R, Geuna A, Grimaldi R, Hughes A, Krabel S, Kitson M, Llerena P, Lissoni F, Salter A, Sobrero M (2013) A review of the literature on universtiy-industrs relations

Radosevic S (1996) 'Restructuring of R\&D institutes in post-socialist economies: emerging patterns and issues', in Webster, A Building new bases for innovation: the transformation of the R\&D system in post-socialist states, Anglia Polytechnic University

Radosevic S (1999) S\&T in growth and restructuring of Central and Eastern Europe: the main pattern and factors of transformation, TSER project paper, SPRU, mimeo

Radosevic S (2003) Patterns of preservation, restructuring and survival: science and technology policy in Russia in post-Soviet era. Res Policy 32:1105-1124

Ranga M, Etzkowitz H (2010) Creative reconstruction: a Triple Helix-based innovation strategy in Central and Eastern Europe countries. Issues and challenges. In: Saad M, Zawdie G (eds) Theory and practice of Triple Helix model in developing countries. Routledge, Oxford, New York, pp 249-282

Ranga M, Etzkowitz H (2013) Triple Helix systems: an analytical framework for innovation policy and practice in the knowledge society. Ind High Educ 27(3):237-262

Sutz J (2000) The university-industry-government relations in Latin America. Res Policy 29(2):279-290

The Great Soviet Encyclopedia, 3rd Edition (1970-1979). @ 2010 The Gale Group, Inc.

UNECE (2014) Innovation performance review, United Nations, 2014

UNESCO (2013) UNESCO Institute for Statistics data, 2013, http://data.uis.unesco.org/

World Bank (2013) Addressing governance at the center of higher education reforms in Armenia report no. 77669

Yerznkyan S (2011) Development of science and technology: the role of the Armenian Diaspora, @ 2011. The World Bank Group, All Rights Reserved, http://go.worldbank.org 